\title{
KÖZÉPISKOLÁSOK NYELVTANULÁSÁNAK EREDMÉNYESSÉGE AZ ANYAGI, KULTURÁLIS ÉS TÁRSADALMI TŐKE TÜKRÉBEN
}

\author{
NOVÁK ILDIKÓ \\ Debreceni Egyetem, Nevelés- és Müvelődéstudományi Doktori Program \\ Beérkezett: 2020, november 22., elfogadva: 2021. május 18.
}

\begin{abstract}
A hatékony középiskolai nyelvtanulás kérdésköre az elmúlt évtizedekben a hazai kutatások középpontjába került. Ezen tanulmány egy gimnáziumi és technikumi tanulók körében folytatott kérdőíves pilot kutatás eredményeit mutatja be, melynek célja volt feltárni a tanulók anyagi, kulturális és társadalmi tőkéje, valamint nyelvtanulási eredményessége között meglévő kapcsolatot. Az eredmények összefüggést mutattak a nyelvtanulási eredményesség és a szülők iskolai végzettsége, a családi könyvtár nagysága és a csoporttagság között, azonban az anyagi tőkével való összefüggés nem volt megfigyelhetö.
\end{abstract}

Kulcsszavak: nyelvtanulás, eredményesség, anyagi tőke, kulturális tőke, társadalmi tőke

The importance of effective foreign language learning in Hungarian secondary schools has become a key focus of research in the last decades. This paper presents the results of a questionnaire-based pilot study conducted among secondary grammar and secondary technical school students to explore the relationship between the language learning effectiveness of the students and their economic, cultural, and social capital. The results showed correlations between language learning effectiveness and parental education, the size of the family library as well as group membership; however, no correlation with economic capital was detected.

Keywords: foreign language learning, effectiveness, economic capital, cultural capital, social capital

\footnotetext{
* Levelező szerző: Novák Ildikó, Debreceni Egyetem, 4032 Debrecen, Egyetem tér 1.

E-mail: ilyesnovakildiko@gmail.com
} 


\section{Bevezetés}

$\mathrm{H}$ azánkban a fiatalok nyelvtudása a rendszerváltás óta lezajlott globalizációs folyamatoknak köszönhetően a kutatások középpontjába került. Egybehangzó vélemény, hogy alapvető közoktatási feladat a fiatalok minél magasabb szintű nyelvtudással történő felvértezése. Korábbi kutatásunkban középiskolai tanulók nyelvtanulási eredményességében mutatkozó különbségeket tártunk fel (Novák-Fónai 2020). Jelen tanulmányunkban azt vizsgáljuk, hogy milyen anyagi, kulturális és társadalmi eltérésekkel magyarázhatók ezek a különbségek. Vagyis jelen tanulmányunkban a nyelvtanulási eredményesség és a különböző tőkefajták közötti összefüggés feltárására teszünk kísérletet.

A tanulmány egy kérdőíves kvantitatív pilot kutatás eredményeit elemzi, melyet 2018 és 2019 fordulóján 105 debreceni gimnáziumi és technikumi tanuló megkérdezésével bonyolítottunk le. A kérdések feltárták a nyelvvizsgával rendelkezők körét, a válaszoló diákok nyelvtudásának szintjét, a jövőbeli nyelvtanulási terveket, a nyelvtanulási sikeresség érzetét, az általános és középiskolai óraszámok, a nyelvtanulást segítő iskolán kívüli eszközök és aktorok szerepét, valamint a gazdasági, kulturális és társadalmi tőke dimenzióit a tanulók körében.

\section{Elméleti háttér}

Elemzésünk szakirodalmi hátterét a meghatározó tőkeelméletek adták; figyelembe vettük a Bourdieu (1999) által meghatározott három fö tőketípust (gazdasági, kulturális, társadalmi), valamint Coleman (1994) társadalmitőke-elméletét.

A nyelvtudásba való befektetés nyilvánvalóan anyagi tőkét igényel a családoktól (Bocsi 2018), de vajon ez a tőke valóban döntően befolyásolja-e a nyelvtanulási eredményességet? Feltételezzük, hogy Boudon (1981) költség-haszon kalkuláció hipotézise a nyelvtanulás tekintetében is müködik, és a különböző értékítélet okoz különbségeket a tanulói elömenetelben.

A család kulturális háttere, valamint a családból hozott nyelvi készségek szintje (pl. a szülők nyelvtudása) az idegen nyelv elsajátítása során is kétségkívül magyarázhatja a különbségeket. Számos tanulmány tárja fel a szülők iskolai végzettségének hatását gyermekeik nyelvtanulási karrierútjára (Imre 2007; Józsa-Nikolov 2005; Kormos-Csizér 2005; Terestyéni 1981; Vágó 2000) beleértve a nyelvválasztást is (Csapó 2001; Lannert-VágóKörösiné 2006). Bizonyos tanulmányok különösen az anyák iskolázottságának hatását hangsúlyozzák a tanulók teljesítményére (Pusztai 2009; Lannert 2004), mely akár a tanulók nyelvérzékét is befolyásolhatja (Ottó-Nikolov 2003). Mások ugyanakkor az apa iskolai végzettségével mérik a kulturális tőkét (Kovai-Zombory 2000; Bocsi 2018).

Bernstein (1971) a középosztály és az alacsonyabb társadalmi rétegek nyelvi kódja (a kidolgozott vagy formális kód és a korlátozott vagy közösségi kód) közötti különbségekben látja az eltérő iskolai sikereik magyarázatát. Ugyanez felvetődik Bourdieu (1978) tanulmányában is, aki szerint az oktatási rendszerbe bekerülve a nyelvi készségekben tapasztalható különbségek miatt a társadalmi egyenlőtlenségek tovább mélyülnek. Boudon (1981) a „kognitív hátrány hipotézis” elméletében csakúgy, mint Bourdieu 
és Bernstein (nyelvikód-elmélet), a nyelvkészletben rejlő különbségek tanulmányi előmenetelre gyakorolt hatását is hangsúlyozza.

Coleman (1990) szerint a tanulmányi eredményességre a tanuló közvetlen környezete, így iskolatársai és barátai is hatnak. A csoporthoz való tartozással egy normarendszerhez igazodik a tanuló, függetlenül társadalmi státuszától (Coleman 1990). Coleman véleménye szerint a vertikális társadalmi viszonyok hatásán túl az iskola egy másik erős hatással bíró társadalmi környezetet nyújt, amely a tanulói viselkedést és döntéshozatalt befolyásolja (Pusztai 2009). Amíg az iskola, mint igen szoros kapcsolatrendszer, nyilvánvalóan hatással van a tanulók döntéseire, addig bizonyos gyenge kötések is befolyásolhatják a tanulókat (Granovetter 1983). Pusztai (2011) felsőoktatási hallgatók között végzett kutatásából is kiderül, hogy a gyengébb, külső kötésekkel rendelkező tanulók tanulmányi eredményei kedvezőbbek. Granovetter (1985) beágyazottságelmélete szerint nem lehetséges az egyén cselekedeteiről egyéni jellemzők szerint véleményt formálni, mert azokat társadalmi folyamatok alakítják.

\section{Kutatási célok, kérdések és módszerek}

Jelen tanulmányunkban az egyes tőkefajták (anyagi, kulturális, társadalmi tőke) és a középiskolai tanulók nyelvtanulási eredményessége közötti kapcsolatot vizsgáljuk. Arra voltunk kíváncsiak, hogy mutatkoznak-e különbségek az egyes tőketípusok megléte vagy hiánya esetén a nyelvvizsgaszerzésben - melyet a nyelvtanulás eredményessége objektív mutatójának tekintünk -, illetve a sikeres nyelvtanulói önértékelésben, mely a nyelvtanulás eredményességének szubjektív megítélését mutatja. A vizsgálat során tehát arra kerestük a választ, hogy mely anyagi, kulturális és társadalmi tőkeelemek függnek össze a nyelvtanulási eredményességgel, valamint hogy eredményesebb nyelvtanulást várhatunk-e ezen tőkefajták erősebb jelenléte esetén. Feltáró jellegü pilot kutatásunk elsődleges célja a mérőeszköz tesztelése volt, melyet később nagyobb mintán kívánunk alkalmazni.

Önkitöltős, nyomtatott kérdőíves, kvantitatív kutatásunkat hét debreceni középiskola (3 technikum és 4 gimnázium) 105 tanulójának megkérdezésével végeztük el 2018 és 2019 fordulóján. A véletlenszerü mintavételi eljárás során szem elött tartottuk, hogy a minta mindenképpen haladja meg a százas elemszámot, közel fele-fele arányban tartalmazzon gimnáziumi és technikumi osztályokat, és vizsgálja a 9-12. évfolyamos és esetleg technikusi évben járó tanulókat. Az évfolyamon belül az osztályokat megint véletlenszerűen választottuk ki. Az eredményeket kereszttáblákkal és Khí-négyzet próbával elemeztük.

A mintába került 9-12. évfolyamos debreceni középiskolai tanulók 49\%-a fiú és 51\%-a lány, megkérdezésük időpontjában 15-20 évesek. Lakhelyük szerint $67 \%$-uk megyeszékhely, $22 \%$-uk egyéb város lakosa, 10\%-uk falun él, míg 1\% fővárosi lakos, 58\%uk gimnáziumban, 42\%-uk technikumban tanul. A szülők iskolai végzettsége szerint a legnagyobb arányban mind az apák (37\%), mind az anyák (40\%) felsőfokú végzettséggel rendelkeznek. A tanulók között az általános iskolában és a középiskolában is az angol nyelv a leggyakoribb első tanult idegen nyelv. 


\section{A nyelvtanulás eredményessége és az anyagi tőke közötti kapcsolat vizsgálata}

\section{Szubjektiv anyagi helyzet}

Az önértékelésen alapuló családi anyagi helyzet és a nyelvtanulás eredményessége között nem kaptunk szignifikáns összefüggést. A válaszokból kiderül, hogy a tanulók több mint háromnegyede (76\%) a legjobb anyagi helyzetű kategóriába sorolja magát, azaz lényegében megvan mindenük, s jelentősebb kiadásokra is telik a családjuknak. A megkérdezett tanulók több mint ötödének (22\%) megvan ugyan mindene, de nagyobb kiadás már nem fér bele a családi költségvetésbe, míg elenyésző (2\%) jelölte azt, hogy családjának van, hogy gondot okoz a mindennapi megélhetés. Ezek az arányok tehát hasonlóképpen alakulnak a vizsgált csoportokban, hozzátéve, hogy a nyelvvizsgával rendelkező, illetve a saját nyelvtudást szubjektíve sikeresnek értékelők körében némiképp kedvezőbb a kép (1. táblázat).

1. táblázat: A nyelvvizsgával való rendelkezés és a nyelvtudás tanulói önértékelése a szubjektív anyagi helyzet tükrében (\%)

\begin{tabular}{lcccc}
\hline & $\begin{array}{l}\text { Elöfordul, hogy a } \\
\text { mindennapi kiadás } \\
\text { is gondot okoz }\end{array}$ & $\begin{array}{l}\text { Mindenünk meg- } \\
\text { van, de nagyobb } \\
\text { kiadásra nem telik }\end{array}$ & $\begin{array}{l}\text { Mindenünk meg- } \\
\text { van, jelentösebb } \\
\text { kiadásokra is telik }\end{array}$ & Összesen \\
\hline \multicolumn{5}{c}{ Nyelvvizsgával való rendelkezés } \\
\hline $\begin{array}{l}\text { Nyelvvizsgával ren- } \\
\text { delkezik }(n=37)\end{array}$ & 0 & 14 & 86 & 100 \\
$\begin{array}{l}\text { Nyelvvizsgával nem } \\
\text { rendelkezik }(n=67)\end{array}$ & 3 & 27 & 70 & 100 \\
\hline \multicolumn{5}{c}{ Nyelvtudás tanulói önértékelése } \\
\hline $\begin{array}{l}\text { Sikeres }(n=82) \\
\text { Nem sikeres }(n=13)\end{array}$ & 0 & 22 & 78 & 100 \\
\hline
\end{tabular}

Forrás: Saját adatfelvétel

\section{Objektiv anyagi belyzet}

Az objektív anyagi helyzet és a nyelvtudás közötti kapcsolat vizsgálatakor az anyagi tőke objektív indikátoraként a családok tulajdonában lévő eszközök és ingatlanok meglétét (saját lakás/ház, nyaraló, gépkocsi, okostelefon, laptop, tablet, széles sávú internethozzáférés) alkalmaztuk. A tulajdoni elemek egyszerü összegzésével indexet készítettünk, és azt vizsgáltuk, hogy az adott tanuló családja a mintaátlag alatti vagy a feletti anyagi helyzettel rendelkezik-e. Ezt az értéket vetettük aztán össze a nyelvtanulás eredményességének objektív és szubjektív mutatóival.

Nem látható szignifikáns összefüggés az objektív anyagi helyzet és a nyelvtanulás eredményessége között, sem a nyelvvizsga meglétével, sem a saját nyelvtudás értékelésével való kapcsolatot vizsgálva. Mintánkban valószínűsíthető tehát, hogy az objektív anyagi helyzet nem játszik meghatározó szerepet a nyelvvizsga megszerzésében, s a 
nyelvtudás tanulói önértékelésében sem (2. táblázat). Mindehhez azért hozzá kell tenni azt is, hogy az általunk az anyagi tőke mutatóiként vizsgált javak vagy általános jellegűek (pl. lakás), vagy a digitalizáció miatt széles körben elterjedtek. Ez mindenképpen közrejátszhat abban, hogy az anyagi javakkal való ellátottság mintánkban nincs kapcsolatban a sikeres nyelvvizsgával és a nyelvtudás szubjektív megítélésével. Ez azt is jelenti, hogy egy későbbi nagymintás kutatásban a vizsgált javak körébe hatékonyabb mutatókat kell majd bevonni.

2. táblázat: A nyelvvizsgával való rendelkezés és a nyelvtudás tanulói önértékelése az objektív anyagi helyzet tükrében (\%)

\begin{tabular}{lccc}
\hline & $\begin{array}{c}\text { Mintaátlag alatti anyagi } \\
\text { helyzet }\end{array}$ & $\begin{array}{c}\text { Mintaátlag feletti anyagi } \\
\text { helyzet }\end{array}$ & Összesen \\
\hline & Nyelvvizsgával való rendelkezés & & \\
\hline $\begin{array}{l}\text { Nyelvvizsgával rendelkezik } \\
(n=36)\end{array}$ & 47 & 53 & 100 \\
$\begin{array}{l}\text { Nyelvvizsgával nem rendel- } \\
\text { kezik }(n=67)\end{array}$ & 49 & 51 & 100 \\
\hline & Nyelvtudás tanulói önértékelése & & 100 \\
\hline Sikeres $(n=81)$ & 47 & 53 & 100 \\
Nem sikeres $(n=13)$ & 49 & 46 &
\end{tabular}

Forrás: Saját adatfelvétel

\section{A nyelvtanulás eredményessége és a kulturális tőke közötti kapcsolat vizsgálata}

A nyelvtanulás és a kulturális tőke közötti összefüggést két területen vizsgáltuk. Egyfelöl a szülök nyelvtudását vontuk be változóként, melyet jelen tanulmányunkban kulturális tőkeként értelmezünk. Másfelől a család kulturális tőkéjét a családi könyvtár nagyságán mértük, melyet tárgyiasult kulturális tőkeként vizsgáltunk.

\section{Szülök nyelvtudása}

Feltételezve, hogy a szülők nyelvtudása befolyással bír mind a tanulók nyelvvizsgaszerzési aspirációjára, mind pedig a nyelvtanulási sikerességükre, ezért megvizsgáltuk a tanulói nyelvtudás (nyelvvizsga megléte, tanulói önértékelés), valamint az édesapák és édesanyák idegen nyelvi beszédkészsége közötti kapcsolatot. Az eredmények szerint a nyelvvizsgával rendelkezők között a nyelvet beszélő anyák (65\%) aránya több mint $20 \%$-ponttal magasabb volt, mint a nyelvvizsgával nem rendelkezők körében. Ugyanez az apák esetében 13\%-pontos különbséget jelent a nyelvet beszélök javára. A magukat sikeresnek gondoló nyelvtanulók 34\%-ponttal nagyobb arányban nyelvet beszélő édesanyák gyermekei, mint a magukat sikertelennek valló csoport tagjai. Ugyanez a szám az apák tekintetében 14\%-pont. Hozzátéve, hogy csak az anyák nyelvtudása kapcsán tapasztaltunk szignifikáns kapcsolatot. A kutatási előzményekhez hasonlóan (Lannert 
3. táblázat: A nyelvvizsgával való rendelkezés és a nyelvtudás tanulói önértékelése az anyai és apai nyelvtudás tükrében (\%)

\begin{tabular}{|c|c|c|c|c|c|c|}
\hline & \multicolumn{3}{|c|}{ Anya beszél nyelvet* } & \multicolumn{3}{|c|}{ Apa beszél nyelvet } \\
\hline & $\mathrm{Nem}$ & Igen & Összesen & Nem & Igen & Összesen \\
\hline \multicolumn{7}{|c|}{ Nyelvvizsgával való rendelkezés* } \\
\hline $\begin{array}{l}\text { Nyelvvizsgával rendel- } \\
\text { kezik }(n=37)\end{array}$ & 35 & 65 & 100 & 49 & 51 & 100 \\
\hline $\begin{array}{l}\text { Nyelvvizsgával nem } \\
\text { rendelkezik }(n=68)\end{array}$ & 57 & 43 & 100 & 62 & 38 & 100 \\
\hline \multicolumn{7}{|c|}{ Nyelvtudás tanulói önértékelése ${ }^{*}$} \\
\hline Sikeres $(n=83)$ & 43 & 57 & 100 & 55 & 45 & 100 \\
\hline Nem sikeres $(n=13)$ & 77 & 23 & 100 & 69 & 31 & 100 \\
\hline
\end{tabular}

Megjegyzés: * $\chi^{2}$-próba, $p<0,05$

Forrás: Saját adatfelvétel

2004; Ottó-Nikolov 2003; Pusztai 2009) eredményeink szerint is meghatározóbb szerepe lehet az édesanyáknak a tanulók nyelvtanulási teljesítményére, mint az édesapáknak (3. táblázat).

\section{Családi könyvtár}

Tárgyiasult kulturális tőkeként a családi könyvtár nagyságát vontuk be a vizsgálatunkba. Miután a tanulókat válaszaik alapján kicsi (néhány polcnyi könyv vagy attól kevesebb), közepes (1-2 könyvszekrény) és nagy (3 vagy ennél több könyvszekrény) házi könyvtárakkal rendelkező csoportokba soroltuk, megvizsgáltuk, hogy a nyelvvizsgával

4. táblázat: A nyelvvizsgával való rendelkezés és a nyelvtudás tanulói önértékelése a családi könyvtár nagyságának tükrében (\%)

\begin{tabular}{|c|c|c|c|c|}
\hline & $\begin{array}{l}\text { Kis családi } \\
\text { könyvtár }\end{array}$ & $\begin{array}{c}\text { Közepes családi } \\
\text { könyvtár }\end{array}$ & $\begin{array}{c}\text { Nagy családi } \\
\text { könyvtár }\end{array}$ & Összesen \\
\hline \multicolumn{5}{|c|}{ Nyelvvizsgával való rendelkezés* } \\
\hline $\begin{array}{l}\text { Nyelvvizsgával ren- } \\
\text { delkezik }(n=37)\end{array}$ & 19 & 19 & 62 & 100 \\
\hline $\begin{array}{l}\text { Nyelvvizsgával nem } \\
\text { rendelkezik }(n=68)\end{array}$ & 38 & 30 & 32 & 100 \\
\hline \multicolumn{5}{|c|}{ Nyelvtudás tanulói önértékelése* } \\
\hline Sikeres $(n=83)$ & 23 & 28 & 49 & 100 \\
\hline Nem sikeres $(n=13)$ & 70 & 15 & 15 & 100 \\
\hline
\end{tabular}


rendelkező, illetve a magukat sikeres nyelvtanulónak gondoló tanulói csoportok családi könyvtára mutat-e jelentős különbséget a nyelvvizsgával nem rendelkező, illetve a sikertelen nyelvtanulókétól.

A nyelvvizsgával rendelkezők döntő többsége (62\%) nagy családi könyvtárral rendelkezik, ez az arány közel duplája a nyelvvizsgával nem rendelkező társaikénak (32\%). A magukat sikeres nyelvtanulónak gondoló diákok körében a nagy családi könyvtárral rendelkezők aránya szintén kiugróan magas (49\%) a sikertelen társaikhoz viszonyítva (15\%). Az eredmények szignifikáns különbséget mutattak a tárgyiasult kulturális tőke és a nyelvtanulási eredményesség között, vagyis a kulturális tőke inkorporált formája amellett, hogy a családok tőkékkel való ellátottságát mutatja, a sikeres nyelvvizsgát is elöre jelezheti (4. táblázat).

\section{A nyelvtanulás eredményessége és a társadalmi tőke közötti kapcsolat vizsgálata}

A társadalmi tökét a különféle szervezetekhez, csoportokhoz, közösségekhez (diákönkormányzat, sportegyesület, vallási közösség, jótékonysági szervezet) való tartozással mértük. Feltételezzük, hogy a csoporttagság a normakövetés miatt az általános tanulmányi eredményesség mellett összefügghet a tanulók nyelvtanulási eredményességével is. Vizsgálatunkban a nyelvvizsga megléte a sportegyesületi, a vallási közösségi, illetve a jótékonysági szervezeti tagsággal mutatott szignifikáns kapcsolatot. A sikeres nyelvtanulói érzet esetén szignifikáns kapcsolatot egyedül a vallási közösséghez való tartozás kapcsán találtunk.

A nyelvvizsgával rendelkezők leginkább sportegyesületi tagságról számoltak be (84\%), tőlük a nyelvvizsgával nem rendelkezők közel 10\%-ponttal maradnak el (74\%). A nyelvvizsgával rendelkezők döntő többsége (83\%) vallási közösség tagja vagy volt tagja, ez az érték a nyelvvizsgával nem rendelkezők körében 25\%-ponttal kevesebb

5. táblázat: A nyelvvizsgával való rendelkezés és a nyelvtudás tanulói értékelése a csoportagság tükrében (\%)

\begin{tabular}{|c|c|c|c|c|}
\hline & \multicolumn{4}{|c|}{ Részt vesz / Tag } \\
\hline & $\begin{array}{l}\text { sportegyesület- } \\
\text { ben }^{*}\end{array}$ & $\begin{array}{l}\text { vallási közösség- } \\
\text { ben* }^{*}\end{array}$ & $\begin{array}{c}\text { diákönkormány- } \\
\text { zatban }\end{array}$ & $\begin{array}{l}\text { jótékonysági } \\
\text { szervezetben* }^{*}\end{array}$ \\
\hline \multicolumn{5}{|c|}{ Nyelvvizsgával való rendelkezés* } \\
\hline $\begin{array}{l}\text { Nyelvvizsgával rendel- } \\
\text { kezik }(n=37)\end{array}$ & 84 & 83 & 31 & 29 \\
\hline $\begin{array}{l}\text { Nyelvvizsgával nem } \\
\text { rendelkezik }(n=67)\end{array}$ & 74 & 58 & 22 & 9 \\
\hline \multicolumn{5}{|c|}{ Nyelvtudás tanulói önértékelése* } \\
\hline Sikeres $(n=80)$ & 74 & 58 & 22 & 9 \\
\hline Nem sikeres $(n=13)$ & 69 & 39 & 23 & 8 \\
\hline
\end{tabular}

Megjegyzés: * $\chi^{2}$-próba, $p<0,05$

Forrás: Saját adatfelvétel 
(58\%). Diákönkormányzati tagságról a nyelvvizsgával rendelkezők 31\%-a számolt be, tőlük $9 \%$-ponttal maradnak el ezen csoporttagságban a nyelvvizsgával nem rendelkezők (22\%). Legkevesebben a jótékonysági szervezeti tagok szerepelnek a mintában, nyelvvizsgával $29 \%$, nyelvvizsga nélkülieknek mindössze 9\%-a tagja ilyen szervezetnek. A nyelvtudás tanulói megítélése tekintetében a vallási közösséghez tartozás kapcsán közel $20 \%$ különbség mutatkozik a sikeres nyelvtanulók javára (5. táblázat). A csoporttagság tekintetében a legnagyobb különbség tehát a vallási közösséghez tartozással kapcsolatban figyelhető meg, ugyanakkor torzíthatta az eredményeket az a tény, hogy az iskolák között két egyházi fenntartású gimnázium is szerepel.

\section{Összegzés}

A mintánkon alapuló eredményeink szerint megfogalmazható, hogy a nyelvtanulási sikerek hátterében az anyagi tőke nem feltétlenül meghatározó tényező, hozzátéve, hogy az anyagi tőke mérését érdemesnek tartjuk sokkal jobban cizellálni. A kulturális tőke kapcsán a szülői, azon belül legerősebben az anyai nyelvtudás függ össze leginkább a tanulók nyelvtanulási eredményességével. A családi könyvtár, mint tárgyiasult kulturális tőke, jelentős mértékű különbséget mutatott a nyelvvizsgával rendelkezők és a sikeresek javára. A társadalmi tőke és a nyelvtanulási eredményesség közötti kapcsolat a nyelvvizsgával rendelkezők körében a vallási közösségi és a jótékony szervezeti tagság esetén mutatkozott erősebbnek. A saját nyelvtudás kedvező szubjektív megítélése mögött a vallási közösségi tagság támogató szerepe rajzolódott ki.

A kutatás alapvető korlátja a mintaválasztás módja, valamint az alacsony elemszám, melyek általánosabb következtetések levonására nem adnak lehetőséget.

\section{IRODALOM}

Bernstein, B. (1971) Class, Codes and Control. London, Routledge \& Kegan Paul.

Bocsi V. (2018) (Kárpát-medencei) Erőforrástérkép - magyar fiatalok az oktatás világában. In: Székely L. (ed.) Magyar fiatalok a Kárpát-medencében - Magyar Ifjúság Kutatás 2016. Budapest, Kutatópont Kft. pp. 183-204.

Boudon, R. (1981) Társadalmi egyenlőtlenségek a továbbtanulásban. In: HaLÁsz G. \& LANNERT J. (eds) Oktatási rendszerek elmélete - szöveggyüjtemény. Budapest, OKKER Kiadó. pp. 406-417.

Bourdieu, P. (1999) Gazdasági tőke, kulturális tőke, társadalmi tőke. In: Angelusz R. (ed.) A társadalmi rétegzödés komponensei. Budapest, Új Mandátum. pp. 156-177.

Coleman, J. (1994) Társadalmi tőke. In: Lengyel Gy. \& Szántó Z. (eds) A gazdasági élet szociológiája. Budapest, Budapesti Közgazdaságtudományi Egyetem. pp. 99-127.

Csapó B. (2001) A nyelvtanulást és a nyelvtudást befolyásoló tényezők. Iskolakultúra, Vol. 11. No. 8. pp. 25-35.

Granovetter, M. (1983) The Strength of Weak Ties: A Network Theory Revisited. Sociological Theory, Vol. 1. pp. 201-233.

Granovetter, M. (1985) Economic Action and Social Structure - The Problem of Embeddedness. American Journal of Sociology, Vol. 91. No. 3. pp. 481-510. 
Imre A. (2007) Nyelvoktatás, nyelvtanulás, nyelvtudás a középfokú oktatásban. In: VÁGó I. (ed.) Fókuszban a nyelvtanulás. Budapest, OFI. pp. 107-129.

Józsa K. \& Nikolov M. (2005) Az angol és német nyelvi készségek fejlettségét befolyásoló tényezők. Magyar Pedagógia, Vol. 105. No. 3. pp. 307-337.

Kormos J. \& Csızér K. (2005) A családi környezet hatása az idegen nyelvi motivációra: egy kvalitatív módszerekkel történő kutatás tanulságai. Magyar Pedagógia, Vol. 105. No. 1. pp. 29-40.

Kovar M. \& Zомвову M. (2000) Idegennyelvi különórák szerepe a középiskolában. Educatio, Vol. 9. No. 4. pp. 842-848.

Lannert J. (2004) Hatékonyság, eredményesség és méltányosság. Új Pedagógiai Szemle, Vol. 54. No. 12. pp. 3-15.

Lannert J., VÁGó I. \& Kőrösiné Mikis M. (2006) A felnőttek digitális írás-és idegennyelvtudása. Budapest, Nemzeti Felnőttképzési Intézet.

NovÁk I. \& FónaI M. (2020) Gimnáziumi és szakgimnáziumi tanulók idegennyelv-tanulási eredményessége. Iskolakultúra, Vol. 30. No. 6. pp. 16-35.

Отто́ I. \& Niкоlov M. (2003) Magyar felsőoktatási intézmények elsőéves hallgatóinak nyelvérzéke. Iskolakultúra, Vol. 13. Nos 6-7. pp. 34-44.

Pusztai G. (2009) Társadalmi tőke és iskola. Budapest, Új Mandátum Könyvkiadó.

Pusztai G. (2011) A láthatatlan kéztöl a baráti kezekig - Hallgatói értelmezö közösségek a felsőoktatásban. Budapest, Új Mandátum Könyvkiadó.

Terestyéni T. (1981) Nyelvtudás Magyarországon. Jel-Kép, No. 4. pp. 59-67.

VÁGó I. (2000) Az idegennyelv-oktatás fö tendenciái a 80-as és 90-es években. Educatio, Vol. 9. No. 4. pp. 668-690.

A cikk a Creative Commons Attribution 4.0 International License (https://creativecommons.org/licenses/ by/4.0/) feltételei szerint publikált Open Access közlemény, melynek szellemében a cikk bármilyen médiumban szabadon felhasználható, megosztható és újraközölhető, feltéve, hogy az eredeti szerző és a közlés helye, illetve a CC License linkje és az esetlegesen végrehajtott módosítások feltüntetésre kerülnek. (SID_1) 